\title{
THE METHODOLOGY OF THE RESEARCH OF EPISTEMOLOGICAL FOUNDATIONS OF UKRAINIAN HISTORICAL AND PEDAGOGICAL NARATIVE (MID-NINETEENTH - LATE TWENTIETH CENTURY)
}

\section{Haliv M. D.}

\section{INTRODUCTION}

In the course of the study of the epistemological foundations of the Ukrainian historical and pedagogical narrative of the mid-nineteenth - late twentieth centuries one must rely on the principles of methodological pluralism and, to some extent, methodological relativism. Methodological pluralism implies multiplicity, multivariance, the alternative use of methodological approaches to solving of the set tasks. Methodological relativism obliges to take into account constant variability, relativity, precariousness, arbitrariness of methodological approaches and the tools of cognition, its dependence on socio-cultural circumstances.

\section{Presenting the main material}

Characterizing the theoretical and methodological principles of the study, we distinguish three levels of methodology: general scientific, specific scientific and instrumental (applied).

The general scientific level of the research is to combine the foundations of the epistemological foundations of analytical and narrative philosophy of history and the defining theoretical and methodological approaches to the solution of scientific problems: axiological, synergetic, paradigmatic, hermeneutical, socio-cultural, civilizational and phenomenological.

The combination of the discourses of analytical and narrative philosophy of history, which are considered pole by their ontological and epistemological positions, may seem unjustified or at least eclectic. Notwithstanding the complex theoretical constructs of these paradigms, we consider it necessary to base our study on the views of those neo-positivists who declare epistemological optimism, rejecting extreme skepticism bordering on agnosticism. The representatives of the analytical philosophy of history, despite the influence of the postmodern tradition, express confidence in the historian's ability to grasp the past at least fragmentarily, reconstruct its event-factual components. In particular, A. Danto wrote in 
1965: historians sometimes manage to come to the true statements about what is past for them ${ }^{1}$. Thus, seeking the epistemological foundations of the Ukrainian historical and pedagogical narrative of the period, we express our confidence in the possibility of an adequate reflection of epistemic foundations in the works of historians of pedagogy.

At the same time, we accept the concepts of narrative philosophy of history, that narrative is inherent in all, without exception, historical and pedagogical works. However, we are strongly opposed to the radical direction of the narrative philosophy of history. As it is well known, the representatives of the latter claim that historical reality is reduced to the framework of a text outside of which, it wasn't, isn't and will not be. Radical narratives deny the objectivity of the knowledge about the past, the historian's ability to reproduce even small details of historical reality, and therefore reject the historical methodology. To adopt such a position would be to acknowledge the unscientific nature of any research that is equivalent to self-denial for a scientist. Instead, we share moderate narrativeconstructive ideas about the existence of opportunities for the historian through the scientific critique of historical sources to learn about historical reality. The proponents of moderate narrative discourse favor interpretation, calling it "construction" or "constructed realism". V. Lectorskyi, in particular, emphasized that any construction involves the presence of a multi-layer and multi-level reality in which it is realized and which it detects and tries to transform. Therefore, the constructiveness of anything is not the evidence of its unrealistic nature ${ }^{2}$. In this view, we interpret our research as a large-scale interpretation based on the "basic data", designed to reconstruct (at the same time and construct) the cognitive, ideological, conscious reality - the knowledge bases of the Ukrainian historical and pedagogical narrative.

The axiological approach is based on the principles of axiology - the doctrine of values, the philosophical theory of values, which clarifies the qualities and properties of objects, phenomena, processes that can satisfy the needs, interests and desires of people ${ }^{3}$. As A. Udod noted, the axiological approach in the scientific study of past human society focuses on the question of the scientist's attitude to the subject of the research. This attitude reflects the value approach to the object and is expressed in valuation judgments ${ }^{4}$. The results of the study depend directly on the

\footnotetext{
${ }^{1}$ Данто А. Аналитеческая философия истории. Москва: Идея-пресс, 2002. С. 34.

2 Лекторский В.А. Реализм, антиреализм, конструктивизм и конструктивный реализм в современной эпистемологии и науке. Конструктивистский подход в эпистемологии и науках о человеке: сб. науч. ст. Москва : Канон+РООИ «Реабилитация», 2009. С. 37.

${ }^{3}$ Філософський енциклопедичний словник. Київ: Абрис, 2002. С. 14.

${ }^{4}$ Удод О. А. Аксіологічний (ціннісний) підхід у методології та методиці історії. Наукові прациі історичного факультету Запорізького державного університету. 2000. Вип. XI. С. 165.
} 
evaluation activity of a historian. The application of an axiological approach allows us to put interpretative and evaluative judgments in our study on a solid foundation of universal (Christian), national, civic, and personal values. In this context, it is appropriate to cite the opinion of the Polish researcher of historical methodology E. Domanska, who noted that at the present stage of the development of science, the reflections on history have more to do with ethics than with epistemology ${ }^{5}$. Considering the axiological approach, the intellectual production of domestic researchers of the history of pedagogy, regardless of its ideological direction, scientific novelty and logic-justifying representativeness, is evaluated only positively and interpreted as universal and at the same time creative. In addition, it is the axiological approach that makes it possible to separate the evaluative judgments of Ukrainian historians of pedagogy from the narrative and factual layer of their narrative, to see their moral, national, political, and personal values.

The chosen axiological position also makes us use the principles of the "national-existential methodology" developed by Drohobych scientists V. Ivanyshyn and P. Ivanyshyn. On this basis, the obligation arises for a researcher, who interprets historical sources and events, to regard the nation as an axial reality that determines both the existence of the individual and his hermeneutical capacity ${ }^{6}$. Recognizing our Ukrainian identity, we will not dissociate ourselves from Ukrainian-centric interpretations, and therefore the interpretation of the fundamental epistoms of the national historical and pedagogical narrative will be carried out on the basis of national values, which we consider to be quite natural phenomenon, justified both from the point of view of cognitive and social science.

The synergistic approach is to be understood as historical and pedagogical phenomenon, a self-organizing system, joined by linear and nonlinear connections, polyphonic, alternative and variational processes, undisclosed and underdeveloped states ${ }^{7}$. The use of the synergistic approach provides the consideration of Ukrainian historical and pedagogical science as a self-organized system, the components of which are manifested in institutional, personal, functional, historiographicalnarrative dimensions. At the same time, each individual work and the set of works of a particular historian of pedagogy can be interpreted as a complex

\footnotetext{
${ }^{5}$ Domańska E. Mikrohistorie. Spotkania w międzyświatach. Poznań : Wydawnictwo Poznańskie, 1999. S. 50.

${ }^{6}$ Іванишин П. Національно-екзистенціальна інтерпретація (основні теоретичні та прагматичні аспекти). Монографія. Дрогобич : «Відродження», 2005. С. 17. C. 37 .

${ }^{7}$ Богуславський М. Структура сучасного історико-педагогічного знання. Шлях освіти. 1999. № 1.
} 
organized intellectual system, saturated with logical and grammatical, persuasive, theoretical and ideological layers, coordinates of time and space (E. Topolskyi), theoretically loaded processes, facts, hidden and expressive cognitive procedures, values and emotional substrates, "narrative logic" (F. Ankersmith).

The paradigmatic approach is based on the theory of scientific revolutions by T. Kuhn, who actually proposed the concept of "a paradigm". Under paradigms, he understood recognized by all scientific achievements, which give the scientific community a model of problemsolving and their solutions over a period of time ${ }^{8}$. According to O. Ruptash, paradigms set the boundaries of the problematic field of a scientific discipline, possible ways of seeking the answers and solution of problems, acceptable stereotypes of the interpretation of scientific discoveries. Despite the understanding of the development of science through the prism of "paradigms" and "scientific communities" only in the field of natural sciences, the humanities have taken a pragmatic approach as well. The concept of paradigm in humanities, according to O. Ruptash, is becoming more meaningful - it is a worldview basis of knowledge and comprehension of the world, which accumulate life experience, value and meaning, beliefs and characteristic of a particular culture, history, social group; the way of thinking'.

The hermeneutical approach is based on hermeneutics - the theory of interpretation of texts, and therefore leads to the use of different mechanisms of interpretation of sources: individual-psychological, social, pedagogical, moral, etc. One of the leading specialists in the philosophical hermeneutics of science G.-G. Gadamer in his work "The truth in the Humanities" (1953) suggested the way to reach the truth through the prism of interpretation and understanding of source information. For this purpose, in his opinion, it is necessary for a researcher to listen to the interpretation and to be in interpretation ${ }^{10}$. The philosopher meant a special type of psychological penetration into the text, through which one understands certain meanings. The relevance of the hermeneutical approach in our study is dictated by the need for a certain empathic understanding of the sources of epistemological constructs used in the texts.

The sociocultural approach is based on understanding of the past, including the intellectual production of scientists - historians of pedagogy, through the lens of sociocultural identities (primarily civilizational, national, religious, social). The sociocultural approach relies on cultural

\footnotetext{
${ }^{8}$ Кун Т. Структура научных революций. Москва : Прогресс, 1977. С. 11. C. $23-24$.

9 Рупташ О. В. Парадигмальний підхід у гуманітарних науках. Нова парадигма. 2014. Вип. 122.

${ }^{10}$ Гадамер Г.-Г. Істина і метод. В 2 т. Київ : Юніверс, 2000. Т. 2. С. 41.
} 
concepts, in particular on understanding the phenomenon of culture. The latter, according to E. Kovalenko acts in three aspects: 1) culture as a program of activity and behavior, as a driving factor of action; 2) culture as a continuity, since culture is the experience of human activity, which is passed on from generation to generation (and culture is not only transmitted on the basis of succession, it is developing, enriching); 3 ) culture as accumulation of social and pedagogical experience. This aspect combines the two previous: socially approved and meaningful experience, which is a program of behavior, is not only transmitted on the basis of succession, but also accumulates, which then allows to present it as a socio-pedagogical historical phenomenon that appears as an object of knowledge ${ }^{11}$. It is important in the context of a sociocultural approach is the concept of "signifying practices" (from the Latin significatum meaningful). This concept refers to the ways and mechanisms by which identity is self-represented and recognized by others ${ }^{12}$. Revealing in the narratives of Ukrainian historians of the pedagogy "signifying practices" makes it possible to get closer to the understanding of their socio-cultural identity models.

It is close to the socio-cultural is the civilizational approach, which, according to G. Kornetov, makes it possible to comprehend the development of the historical-pedagogical process, taking fully into account the material-economic, socio-political and spiritual-moral foundations in history. The object of attention of the civilization approach is the totality of all forms of life of a society - material, ideological, cultural, religious, moral, etc. - in unity and gravity. Moreover, the anthropocentricity and cultural correspondence of the civilizational approach give such a view to the historical and pedagogical process, through which the problem of the essential forces of a man in the concrete and historical multifaceted forms of social being arises and solves ${ }^{13}$. In the study of the historical and pedagogical narrative of domestic scientists the civilizational approach serves as means of knowledge of civilizational visions and identities of authors.

The phenomenological approach, according to E. Kovalenko's definition, means that the elements of pedagogical knowledge are analyzed not simply as a historical constanta, but as the derived from the subjective world of a pedagogue, as a product of individual and social consciousness

${ }^{11}$ Коваленко Є.І. Методологічна функція історії педагогіки у становленні майбутнього педагога. Наукові записки Ніжинського державного університету ім. Миколи Гоголя. Серія : Психологопедагогічні науки. 2012. № 4. С. 29-30.

12 Нагорна Л.П. Соціокультурна ідентичність: пастки ціннісних розмежувань. Київ : ІПіЕНД ім. І. Ф. Кураса НАН України, 2011. С. 57.

${ }^{13}$ Корнетов Г. Б. Теория истории педагогики : монография. Москва : АСОУ, 2013. С. 178-179. 
and experience, and its different sides are revealed as indices of subjective understanding (subjectivity in dyads: knowledge - the personality of a scientist; knowledge - the scientific tradition; knowledge - the scientific community), the individual-historical trajectories of his formation are determined and developed ${ }^{14}$. In revealing the epistemological foundations of the Ukrainian historical and pedagogical narrative, the phenomenological approach is manifested in the explication of the subjective, spiritual, personal, and biographical factor. It directs to the discovery of the "inner world" of historians of pedagogy, their outlook, interests, life senses.

The specific scientific level of the methodology of the research is represented by narrative, imaginary, biographical and prosopographic, synchronous-diachronic, lymological (regional), systematic and complex approaches, as well as combining the principles of historicism, scientificity, objectivity and multifactoriality, priority of documentary factors.

The narrative approach firmly integrated in the methodology of Ukrainian historical and pedagogical science. O. Sukhomlynska noted the absolute narrative for all published scientific works of historical nature ${ }^{15}$. The use of the narrative approach is justified by the understanding that scientific knowledge is represented primarily by narrative - the textual form of presenting the research, its results. Of course, there is also a nonnarrative form of scientific knowledge - the intellectual-thinking rationalempirical activity of a scientist, which is much broader, more extensive and more thorough than its narrative embodiment. However, it is narrative that is a platform for the provision of scientific knowledge for the "republic of scientists". The use of a narrative approach makes it possible to view the heritage of national pedagogical historians as a "meta-narrative" - a large text that has cultural, intellectual traditions and is an imaginary entity characterized by gravity.

The imagiological approach is a concrete scientific manifestation of general scientific socio-cultural and civilizational approaches and relies on imagiology as a theory of interpretation of the images of "other" / "alien". According to I. Kutsym, an essential feature of any culture is the differentiation of its inner ("one's own") from the outer ("alien") space. By distinguishing the inner from the outer, an individual determines his / her belonging to a particular culture. In the process of cultural self-

\footnotetext{
${ }^{14}$ Коваленко Є.I. Методологічна функція історії педагогіки у становленні майбутнього педагога. Наукові записки Ніжинського державного університету ім. Миколи Гоголя. Серія : Психологопедагогічні науки. 2012. № 4. С. 30.

${ }^{15}$ Сухомлинська О. Історико-педагогічне дослідження та його «околиці». Шлях освіти. 2005. № 4. C. 45 .
} 
identification, the symbolic notion of the boundary of cultural space plays a key role. The inner space is designated as "our", "native", "safe", "cultural", etc. as opposed to "other", "alien", "hostile", "dangerous", which clearly distinguishes from "one's own". Scientists refer the image of "other" / "alien" as the most ancient archetypal ideas, and the binary opposition "native" / "alien" to the basic universals of human consciousness ${ }^{16}$. The imagiological approach makes it possible to identify the tactics of "otherness" used in the Ukrainian historical and pedagogical narrative of the time outlined.

The biographical approach is a comprehensive study of a personal life path (in this case, a national historian of pedagogy) against the background of the era. According to G. Belan, the scientific biography and creative work of a person is not only the interpretation of his scientific reflections, but also the evidence of worldviews, life concepts, which are the unique reflection of the social processes of the historical era ${ }^{17}$. O. Sukhomlynska actively uses the notion "pedagogical persona", which means something more than a scientific, educational or creative biography, rather a personalized process of formation of values, culture within the humanitarian tradition, and its specific model ${ }^{18}$. This understanding approaches such areas of historical research as historical prosopography and intellectual biography. Therefore, in the context of biographical and prosopographic approaches, the views of historians of pedagogy on the past are explored.

The synchronic-diachronic approach ensures the optimum of the temporal composition of our narrative. According to E. Topolskyi, all types of historical works can be placed on an axis that stretches between the composition that reflects the passage of time from the past to the future, and one that refers to a specific time-lapse, but does not show a chronological sequence of events. And the real narrations are the mixture of diachrony and synchrony ${ }^{19}$. Paying attention to the considerable time span (approximately one and a half century) that encompasses our study, the presentation of the material is built more on a diachronic type of composition, at the same time synchrony was manifested in comparing the ideas of Ukrainian historians of pedagogy of the Overdnipro and Western Ukrainian lands, as well as of the Ukrainian diaspora.

\footnotetext{
${ }^{16}$ Куций I. Цивілізаційні ідентичності в українській історіографії кінця XVIII - початку XX ст. : між Слов’янщиною та Європою. Тернопіль : Підручники і посібники, 2016. С. 33-34.

17 Бєлан Г. В. Біографічний метод в історико-педагогічній науці: провідні тенденції становлення. Педагогічний дискурс. Хмельницький, 2013. Вип. 15. С. 50.

${ }^{18}$ Сухомлинська О.В. Історико-педагогічний процес : нові підходи до загальних проблем. Київ : А.П.Н., 2003. С. 42.

19 Топольський С. Як ми пишемо і розуміємо історію : Таємниці історичної нарації. Київ : К.І.С., 2012. C. 126.
} 
The lemological (regional) approach is dictated by the need to take into account the political affiliation of different regions of Ukraine to foreign countries (Russian and Austro-Hungarian empires, Poland, Czechoslovakia, Romania, the USSR) in the studied era. Of course, a political factor is important, but not decisive, in shaping the content of the regional approach. According to Y. Vermenych, who develops the theory of historical regionalism, it is necessary to change the traditional sociopolitical component of this trend into a socio-cultural one ${ }^{20}$. According to O. Sukhomlynska, the regional approach is based on the understanding of the region as a social and geographical space, where human socialization, formation, preservation and translation of life forms take place ${ }^{21}$. Taking into account the socio-cultural identities of historians of pedagogy as the representatives of a particular region is necessary to understand the knowledge-based principles of their narrative.

We treat the systemic approach as a concrete and scientific embodiment of synergetics. According to E. Kovalenko, a systematic approach requires to explore any historical and pedagogical phenomenon as a systemic formation, highlighting the features of the system: the presence of aggregate elements, each of which is a minimal unit having a limit of division within this system; the presence of certain links and relationships between the system elements; the functioning of the system and its properties due to its structural specificity; the presence in the system of a certain level of integrity, that is, the internal integrative qualities that result from the interaction of its elements; the presence of a common structure that integrates all elements of the system and ensures the completeness of the named elements and coherence of all their functions; the availability of connections to other systems; the dedication of the system to solving some problem ${ }^{22}$. This approach makes it possible to consider all the "specific texts" and "great texts" of national historians within the framework of the imagined cultural and scientific phenomenon - the Ukrainian historical and pedagogical narrative. At the same time, it is the systematic approach that allows to systematize the epistemological foundations of the narrative, dividing them into worldphilosophical, political-ideological, socio-cultural, scientific-interdisciplinary, methodological-instrumental. Closely related to the systematic approach is the comprehensive approach that examines the

20 Верменич Я. Нова локальна історія та історична регіоналістика: експлікація термінів. Регіональна історія України. Вип. 1. С. 13-19.

${ }^{21}$ Сухомлинська О. Історико-педагогічний процес в Україні: регіональний вимір. Шлях освіти. 2007. № 2. С. 42

${ }^{22}$ Коваленко Є.І. Методологічна функція історії педагогіки у становленні майбутнього педагога. Наукові записки Ніжинського державного університету ім. Миколи Гоголя. Серія: Психологопедагогічні науки. 2012. № 4. С. 29. 
object and subject of the research, the scientific problem from the standpoint of integrity and the systematic nature itself.

The principle of historicism is to take into account the specific historical conditions of the formation of epistemological foundations of the Ukrainian historical and pedagogical narrative. The principle of scientificity captures the basic features of science and is associated with the way of verifying the truth for the subject in accordance with the canons of rationality: evidence, argumentation, validity, consistency, reproducibility, naturalness, causality, etc. The principle of objectivity requires the reconstruction of the views and ideas of historians of pedagogy impartially, avoiding distortions, exaggerations, and base on the criticism of the sources. The principle of multifactoriality is to involve and take into account the whole complex of information about the events, phenomena, processes and other factors that influenced the development of the epistemological foundations of the Ukrainian historical and pedagogical narrative of the mid-nineteenth and late twentieth centuries.

The applied level of methodological representation is represented by the application of the research methods - general scientific (abstraction, analysis and synthesis, induction, deduction, classification, generalization), interdisciplinary (context-interpretation, cognitive mapping, lexicosemantic and logical-semantic, critical, structural semantic) and special historical (historical-genetic, historical-comparative, historical-typological, historical-systemic, periodization, retrospective).

The contextual-interpretative method allows us to establish the contexts of the formation and reception of the epistemological foundations by Ukrainian historians of pedagogy and, based on the contextualization of the actual interpretation of the information contained in the narratives. The use of the method of cognitive mapping provides a certain reflection of the causal multilevel epistemological program of historical and pedagogical texts by predication (recognition and selection of the optimal hypothesis) and its cognitive modeling in the form of a simplified, schematized "map". Lexical and semantic methods are needed to clarify the semantic aspects of the metaphors and tropes of the language of historians of pedagogy. Critical and structural-systemic methods make it possible to avoid tendencies in the selection and interpretation of historical and pedagogical texts of Ukrainian scholars.

The use of historical-genetic method makes it possible to trace the genesis of the epistemological ideas on which the narratives of national pedagogy were based. Historical-comparative method provides an opportunity to identify common and different views of scientists on different issues of the past development of education and pedagogy on the 
basis of comparing the historical and pedagogical works of different authors at different times. The use of the historical-system method is the key to building the material in proper consistency, coherence and holicity. The historical-typological method should be used to determine the typological affiliation (civilizational, national, religious, etc.) of the basic concepts of the researchers of the historical and pedagogical past. In the analysis of the historiography of the problem, the method of retrospection was applied, which allows to outline the main achievements in the field of the study of the history of historical and pedagogical science.

The categorical thesaurus used in the research is also of methodological significance: epistemological foundations, narratives, Ukrainian historical and pedagogical narratives.

Epistemology is a branch of philosophy that explores historical knowledge evolving scientifically in its all socio-cultural dimensions. At the center of the problematic field of epistemology are the questions concerning the nature of cognition, its genesis, historical evolution, the conditions of reliability of its results, historical change of its structure, socio-cultural status, strategic goals, relationships with the life experience and all diversity of socio-cultural practices ${ }^{23}$. Many scientists outlined epistemology by comparing it with "gnoseology". Some of them believe that gnoseology and epistemology are identical in content, but in German philosophy the theory of knowledge is called "gnoseology", and in French and Anglo-American the expression "epistemology" is common. Therefore, these words can be used as synonyms.

In most western countries, according to V. Petrushenko, epistemology is mainly associated with the study of scientific knowledge only, while gnoseology traditionally studied the processes and forms of cognitive activity at all its levels and in all manifestations ${ }^{24}$. Recognizing the interaction of epistemology and gnoseology (as well as knowledge and cognition), V. Petrushenko himself, of course, separated them, emphasizing the connection of gnoseology with the traditions of classical science, and epistemology with the models of non-classical philosophy ${ }^{25}$. He expanded the subject of epistemology from the study of the scientific to the understanding of any knowledge as a phenomenon. However, a narrow understanding of the subject of epistemology is acceptable to us, since the object of the study is historical and pedagogical knowledge as the product of scientific thinking, that is, scientific knowledge itself.

\footnotetext{
${ }^{23}$ Філософський енциклопедичний словник. Київ : Абрис, 2002. С. 202.

${ }^{24}$ Петрушенко В.Л. Епістемологія як філософська теорія знання. Львів : Вид-во ДУ «Львівська політехніка», 2000. С. 3.

${ }^{25}$ Петрушенко В.Л. Епістемологія...С. 27.
} 
Under epistemological principles we mean the defining epistemic constructs that underlie in the foundation of knowledge: ideologicalphilosophic, political-ideological, socio-cultural, scientificinterdisciplinary and disciplinary (historical and pedagogical). The concept of "epistemological foundations" can be compared with the concept of "episteme", proposed by M. Foucault. The philosopher understood by the "episteme" a set of relationships that can unite language practices in a particular era. An episteme is not a form of cognition or a type of rationality that, when intersecting with various sciences, would express the sovereign unity of the subject, spirit, or the epoch: it is the totality of relations that can be opened to a given era between the sciences when we analyze them in levels of language patterns. M. Foucault emphasized that the episteme is an infinitely moving figure, and its description can never be completed $^{26}$.

In the context of nomination of epistemological foundations, it is important to understand the structure of historical and pedagogical knowledge. One of the few publications on this issue is an article by Russian scientist M. Boguslavskyi ${ }^{27}$. It presents a four-part construct of the structure of historical and pedagogical knowledge: 1) worldview position in the interpretation of the phenomena of the past (materialistic-deterministic, transcendental (religious), synergistic worldview); 2) the scope of general approaches to the study of world history of education (formational, anthropological, civilizational approaches); 3) general research methods (historical-structural, structural-genetic, historical-comparative methods); 4) partial research methods (axiological, large innovation schemes, wave, modernization, monographic, paradigmatic).

Such way of structuring of scientific historical and pedagogical knowledge seems to us insufficiently substantiated, as it is very similar to the structure of the methodology of scientific research: firstly outlook, then philosophical approaches (and the latter can determine outlook), and finally, specific methods and techniques. In addition, such construction raises the questions about the lack of a specific scientific level of methodology, represented by regional, paradigmatic, biographical approaches, etc. in this scheme. Among the general (philosophical) approaches the scientist did not mention hermeneutical, phenomenological, ontological and others. Granting by Boguslavskyi the synergistic, generalscientific approach a world-view status seems doubtful. It is not quite clear the characteristic of the methods: special-historical methods (historical-

${ }^{26}$ Фуко М. Археологія знання. Київ : Вид-во Соломії Павличко «Основи», 2003. С. 298.

27 Богуславський М. Структура сучасного історико-педагогічного знання. Шлях освіти. 1999. № 1 (11). С. 37-40. 
structural, historical-genetic, historical-comparative) the scientist refers to the general methods of a research, but for some reason forgets about the analysis, synthesis, generalizations and other, actually general methods of any scientific research. After all, it is unclear why axiological, paradigmatic approaches are among the "partial methods" and in the status of "methods".

Of course, there is no denying that any methodological approach is the part of epistemology (as well as gnoseology). The knowledge of methods is also knowledge, so it is entirely within the field of epistemology, and the use of methods for obtaining certain knowledge puts the content of gnoseological procedures, which can be interpreted as a procedural and dynamic component of knowledge, and therefore again to be included in the field of the interests of epistemology.

However, M. Boguslavskyi's vision of the structure of knowledge in a predominantly dynamic plane is still inferior to the vision of the structure of knowledge largely in a static dimension. The actual isolation of the structure of a particular phenomenon requires fixing it as an established phenomenon. For this reason, we prefer the traditional division of knowledge into two structural components: 1) extracurricular knowledge a set of knowledge (ideological, professional and even household) and values (moral, national, civic, etc.) of a researcher which predetermine the scientific questions, the formulation of problems, selection of sources, and thus have a decisive influence on the construction of the historical and pedagogical past. The components (and thus the epistemological foundations) of this component are: ideologic-philosophical, politicalideological, socio-cultural, interdisciplinary and disciplinary, instrumental and methodological knowledge; 2) source knowledge - knowledge separated from historical (historical and pedagogical) sources by means of scientific and methodological tools and presented by historical and pedagogical facts. The very methodology of the source criticism belongs to the extra-original component of knowledge, but its application allows a researcher to form source knowledge, which is often nominated by the notion of "fact" and is certainly the epistemological basis of the narrative.

The notion of "narrative" ("narration") is one of the major terminological innovations of postmodern philosophy of science to modern humanities. In philosophical dictionaries, "narrative" is largely defined as the notion of philosophy of postmodernism, which captures the procedural process of self-realization as the way of text being ${ }^{28}$. As L. Vakhovskyi points out, narrative in the context of historiography interprets the meaning of a historical event not as a historical process conditioned by objective

\footnotetext{
${ }^{28}$ Новейший философский словарь. Минск : Книжный Дом, 2003. С. 656.
} 
regularity, but as narrative arising in the context of an event and inherently related to the interpretation. So, according to the concept of "narrative history", history is not what it really was in the past, but what we tell about the past is a story about the past ${ }^{29}$. Narrative, therefore, is a textual form of knowledge being.

The notion "Ukrainian historical and pedagogical narrative" is defined as the totality of historical and pedagogical heritage (metatext) of the researchers of the past of education and pedagogical thought who resided in the territory of Ukraine or abroad within the Ukrainian diaspora. Considering that the Ukrainian lands in the studied era belonged to the number of foreign states, the only possibility to outline the affiliation of pedagogical historians to the "Ukrainian historical and pedagogical narrative" is the vision of the Ukrainian historical and geographical space through the prism of modern political borders. In this case, the principle of territoriality is crucial, instead the notion of ethnicity and even national identity of the historian of pedagogy becomes less important. Therefore, the texts of not only ethnic Ukrainians, but also the scholars of other nations have to be included in the "Ukrainian historical and pedagogical narrative". Among them, two cohorts of pedagogical historians should be distinguished: 1) those who identified themselves with the Ukrainian people (eg, S. Rusov), 2) those who identified themselves with Russian, Polish, or any other people, but who lived in Ukraine for a long time also revealed certain regional (local-regional) identity (A. Vanchura, S. Golubjev, F. Titov, etc.). In the case of the representatives of the Ukrainian diaspora, the only way of referring the scientist's works to the "Ukrainian historical and pedagogical narrative" is precisely the Ukrainian national identity of the author of the texts. Therefore, the national historical and pedagogical narrative acts as an imagined cultural and scientific phenomenon, reconstructed on the basis of biographical, historiographical, historical facts, constructed on the basis of gravity, cumulativeness, paradigmality, holicity, coherence, functionality and distinguished territory and identity markers.

As the notion of "pedagogy" is interpreted in the broadest sense of the word, we also interpret the history of pedagogy as: a) the past not only of pedagogy-science, but also for pedagogy-sphere of social life, represented by the realization of pedagogical experience, education of the younger generations; b) presented in the scientific and popular science narratives of the study of the past. That is why we include the works on the history of education and schooling, the history of pedagogical thought, and

${ }^{29}$ Ваховський Л.Ц. Наратив у історико-педагогічному дослідженні: методологічний аналіз. Шлях освіти. 2007. № 1. С. 43. 
pedagogical personality into the "Ukrainian historical and pedagogical narrative".

\section{CONCLUSIONS}

Thus, the theoretical and methodological foundations of the study included general scientific (axiological, synergistic, paradigmatic, hermeneutic, sociocultural, civilizational and phenomenological), specifically scientific (narrative, imaginary, biographical and prosopographic, synchronic diachronic, limological, systemic, complex) approaches and applied mechanisms (general scientific, interdisciplinary and special historical methods). The definitions of "epistemological foundations", "narratives", "Ukrainian historical and pedagogical narratives" are given in the work.

\section{SUMMARY}

The section identifies the methodological foundations of the study of the epistemological foundations of the Ukrainian historical pedagogical narrative (mid-nineteenth and late twentieth centuries), which relied on general scientific, specific scientific, and instrumental and applied levels of methodology. The general scientific level is to combine the basic epistemological foundations of the analytical and narrative philosophy of history and axiological, synergistic, paradigmatic, hermeneutic, sociocultural, civilizational and phenomenological approaches. The specific scientific level is represented by narrative, imaginary, biographical and prosopographic, synchronic-diachronic, lymological (regional), systemic and complex approaches, as well as the combination of the principles of historicism, scientificity, objectivity and multifactoriality. The instrumental and applied level is represented by the application of general scientific (abstraction, analysis and synthesis, induction, deduction, classification, generalization), interdisciplinary (contextual-interpretative, cognitive mapping, lexico-semantic and logical-semantic, critic, structural-systemic) and specific historical (historical-genetic, historical-comparative, historical-typological, historical-systemic, periodization, retrospective) research methods. The section defines the notions "epistemological foundations" and "Ukrainian historical and pedagogical narrative".

\section{REFERENCES}

1. Бєлан Г.В. Біографічний метод в історико-педагогічній науці: провідні тенденції становлення. Педагогічний дискурс. 2013. Вип. 15. С. 50-54. 
2. Богуславський М. Структура сучасного історико-педагогічного знання. Шлях освіти. 1999. № 1. С. 37-40.

3. Ваховський Л.Ц. Наратив у історико-педагогічному дослідженні: методологічний аналіз. Шлях освіти. 2007. № 1. С. 42-45.

4. Верменич Я. Нова локальна історія та історична регіоналістика: експлікація термінів. Регіональна історія Украйни. 2010. Вип. 1. C. $13-19$.

5. Гадамер Г.-Г. Істина і метод. В 2 т. Київ: Юніверс, 2000. Т. 2. $500 \mathrm{c}$.

6. Данто А. Аналитеческая философия истории. Москва: Идеяпресс, 2002. 290 с.

7. Іванишин П. Національно-екзистенціальна інтерпретація (основні теоретичні та прагматичні аспекти). Монографія. Дрогобич: "Відродження", 2005. 308 с.

8. Коваленко Є.I. Методологічна функція історії педагогіки у становленні майбутнього педагога. Наукові записки Ніжинського державного університету ім. М. Гоголя. Серія: Психолого-педагогічні науки. 2012. № 4. С. 27-34.

9. Корнетов Г.Б. Теория истории педагогики: монография. Москва: АСОУ, 2013. 460 с.

10. Кун Т. Структура научных революций. Москва: Прогресс, 1977. $300 \mathrm{c.}$

11. Куций I. Цивілізаційні ідентичності в українській історіографії кінця XVIII - початку XX ст.: між Слов'янщиною та Європою. Тернопіль, 2016. 480 с.

12. Лекторский В.А. Реализм, антиреализм, конструктивизм и конструктивный реализм в современной эпистемологии и науке. Конструктивистский подход в эпистемологии и науках о человеке. Москва, 2009. С. 5-40.

13. Нагорна Л.П. Соціокультурна ідентичність: пастки ціннісних розмежувань. Київ, 2011.272 с.

14. Новейший философский словарь. Минск: Книжный Дом, 2003. $1280 \mathrm{c}$.

15. Петрушенко В.Л. Епістемологія як філософська теорія знання. Львів: Вид-во ДУ “Львівська політехніка”, 2000. 295 с.

16. Рупташ О.В. Парадигмальний підхід у гуманітарних науках. Нова парадигма. 2014. Вип. 122. С. 20-32.

17. Сухомлинська О. Історико-педагогічне дослідження та його “околиці”. Шлях освіти. 2005. № 4. С. 43-47.

18. Сухомлинська О. Історико-педагогічний процес в Україні: регіональний вимір. Шлях освіти. 2007. № 2. С. 42-49. 
19. Сухомлинська О.В. Історико-педагогічний процес: нові підходи до загальних проблем. Київ : А.П.Н., 2003. 68 с.

20. Топольський С. Як ми пишемо і розуміємо історію: Таємниці історичної нарації. Київ: К.І.С., 2012. 400 с.

21. Удод О. А. Аксіологічний (ціннісний) підхід у методології та методиці історії. Наукові праці історичного факультету Запорізького державного університету. 2000. Вип. XI. С. 164-173.

22. Філософський енциклопедичний словник. Київ: Абрис, 2002. $742 \mathrm{c}$.

23. Фуко М. Археологія знання. Київ: “Основи”, 2003. 326 с.

24. Domańska E. Mikrohistorie. Spotkania w międzyświatach. Poznań: Wydawnictwo Poznańskie, 1999. 337 s.

\section{Information about the author:}

Haliv M. D.

Candidate of Pedagogic Sciences, Associate Professor at the Department of History of Ukraine, Ivan Franko Drohobych State Pedagogical University 24, I. Franko str., Drohobych, Lviv region, 82100, Ukraine 